\title{
FATAL ACCIDENTS AT WORK IN AGRICULTURE ASSOCIATED WITH ALCOHOL INTOXICATION IN LOWER SILESIA IN POLAND
}

\author{
ŚMIERTELNE WYPADKI PRZY PRACY W ROLNICTWIE NA DOLNYM ŚLĄSKU W POLSCE \\ ZWIAZZANE Z UPOJENIEM ALKOHOLOWYM
}

Wroclaw Medical University / Uniwersytet Medyczny we Wrocławiu, Wrocław, Poland

Faculty of Medicine, Department of Forensic Medicine / Wydział Lekarski, Katedra Medycyny Sądowej

${ }^{1}$ Zakład Medycyny Sądowej / Forensic Medicine Unit

Zakład Prawa Medycznego / Medical Law Unit

\begin{abstract}
Background: Determining the prevalence of alcohol intoxication and the level of intoxication in victims of fatal occupational accidents is necessary to improve work safety. The circumstances of the accident and the time between alcohol consumption and death are important factors. Material and Methods: A retrospective review of 18935 medico-legal autopsy reports and toxicological reports performed in the Department of Forensic Medicine at the Wroclaw Medical University, Poland, in the years 1991-2014. The study protocol included circumstances, time and cause of death, injuries, quantitative testing for the presence of ethyl alcohol, gender and age. Results: There were $98 \mathrm{farm}$-related fatalities. There were $41.8 \%(\mathrm{~N}=41)$ of victims who had been intoxicated $-95.1 \%(\mathrm{~N}=39)$ of them were males aged 19-70 years old, $4.9 \%(\mathrm{~N}=2)$ were females aged $37-65$ years old. In 8 cases the blood alcohol concentration (BAC) was $50-150 \mathrm{mg} / \mathrm{dl}$; in 15 cases it was $150-250 \mathrm{mg} / \mathrm{dl}$ and in 18 cases it was > $250 \mathrm{mg} / \mathrm{dl}$. In 21 cases, the BAC was determined using alternative material and $76 \%(\mathrm{~N}=16)$ victims were in the alcohol elimination phase with $19 \%(\mathrm{~N}=4)$ victims in the alcohol absorption phase. The most common causes of death were traffic accidents, drowning and deaths resulting from being caught in or hit by moving parts of machinery or equipment. Conclusions: Alcohol consumption is a crucial risk factor in fatal agricultural accidents. In order to establish the time of alcohol consumption, all victims of agricultural accidents should be tested for alcohol concentration in their blood and urine or vitreous. Improving safety at work requires that the sobriety of employees should be monitored before and during work. Med Pr 2017;68(1):23-30
\end{abstract}

Key words: alcohol, agriculture, occupational injuries, blood alcohol concentration, forensic toxicology, work-related deaths

\section{STRESZCZENIE}

Wstęp: W celu poprawy poziomu bezpieczeństwa pracy w rolnictwie konieczne są gromadzenie i analiza danych dotyczących liczby osób w stanie nietrzeźwości, które ulegają śmiertelnym wypadkom, poziomu alkoholu w ich organizmie, okoliczności śmierci i czasu między konsumpcją alkoholu a zgonem. Materiał i metody: Przeprowadzono retrospektywną analizę wyników 18935 sądowo-lekarskich sekcji zwłok i raportów toksykologicznych wykonanych w Katedrze Medycyny Sądowej na Uniwersytecie Medycznym we Wrocławiu w latach 1991-2014. Protokół badania obejmował okoliczności, czas i przyczynę zgonu, obrażenia, wynik badania ilościowego na zawartość alkoholu, płeć i wiek badanych. Wyniki: Stwierdzono 98 wypadków śmiertelnych przy pracy w rolnictwie. Pod wpływem alkoholu było 41,8\% ( N = 41) ofiar wypadków, w tym 95,1\% $(\mathrm{N}=39)$ mężczyzn w wieku 19-70 lat i 4,9\% $(\mathrm{N}=2)$ kobiet w wieku 37-65 lat. W przypadku 8 osób stężenie alkoholu we krwi wynosiło 0,5-1,5\%, u 15 osób - 1,5-2,5\%o, a u 18 osób - powyżej 2,5\%. U 21 ofiar wypadków poziom alkoholu oznaczono w materiale alternatywnym i ustalono, że $76 \%(\mathrm{~N}=16) \mathrm{z}$ nich znajdowało się $\mathrm{w}$ fazie eliminacji alkoholu z organizmu, a $19 \%(\mathrm{~N}=4) \mathrm{w}$ fazie wchłaniania. Najczęstszymi okolicznościami śmierci były wypadki drogowe, utonięcia i urazy związane z pochwyceniem lub uderzeniem przez poruszające się elementy maszyn rolniczych. Wnioski: Spożycie alkoholu jest istotnym czynnikiem ryzyka śmiertelnych wypadków w rolnictwie. W celu ustalenia czasu konsumpcji alkoholu przez ofiary wypadków należy oznaczać u nich stężenie alkoholu we krwi i w moczu lub szklistce. Poprawa bezpieczeństwa w miejscu pracy wymaga monitorowania trzeźwości pracowników zarówno przed rozpoczęciem pracy, jak i w jej trakcie. Med. Pr. 2017;68(1):23-30

Słowa kluczowe: alkohol, rolnictwo, wypadki przy pracy, stężenie alkoholu we krwi, toksykologia sądowa, zgony związane z pracą

Corresponding author / Autor do korespondencji: Tomasz Jurek, Wroclaw Medical University, Faculty of Medicine, Department of Forensic Medicine, Forensic Medicine Unit, Mikulicza-Radeckiego 4, 50-345 Wrocław, Poland, e-mail: tomasz.jurek@umed.wroc.pl Received: December 28, 2015, accepted: August 8, 2016 


\section{INTRODUCTION}

Agriculture ranks among the most dangerous occupations. In Europe, the fatal work-related accident incidence rate in agriculture in 2008 was 19.1 per 100000 workers [1]. According to the statistics from the Polish Central Statistical Office (Główny Urząd Statystyczny - GUS), in 2013 the total accident rate equaled 10.85 per 1000 farm workers and the rate of fatal accidents was 0.101 per 1000 farm workers. Those indicators were much lower in other industries (excluding agriculture): the accident rate of 7.55 per 1000 employees and only 0.024 fatal accidents [2]. Apart from many other factors, the human factor still remains the most important risk factor for occupational accidents $[3,4]$.

The specificity of agricultural professions is that employees are often deprived of adequate supervision, work is carried out independently (no cross-checking), people work in different types of private farms which are often run by owners, family or friends who lack adequate training (relating to health and safety rules), personal protection equipment is not used and no health checks are performed by occupational physicians. The influence of work safety institutions is limited outside bigger farms and the independent nature of the work results in a lack of discipline and workers fail to comply with safety rules, including those forbidding excessive alcohol consumption. It is a well-known fact that one of the major human risk factors at work is alcohol consumption, which is particularly evident in agriculture [5-11].

Many researchers have assessed the scale of this phenomenon based on demographic differences and on the nature of the work by providing detailed epidemiological data [6,7,12-15]. Studies indicate that although many systemic solutions have been introduced (e.g., installation of breathalyzers in agricultural machinery to prevent operation by intoxicated workers), the problem still exists and accidents related to alcohol abuse (including death) pose a serious threat to safety.

The aim of this study has been to retrospectively analyze the incidence of intoxication and the degree of intoxication in fatal farm-related accidents in the Lower Silesia, Poland, taking the circumstances of the incidents and the time between alcohol consumption and death into account.

\section{MATERIAL AND METHODS}

A retrospective review of 18935 medico-legal autopsy reports and toxicological reports established by the
Department of Forensic Medicine in Wrocław, Poland, was conducted by the authors in the years 1991-2014 which included 98 fatal farm-related incidents. The victims came from the Lower Silesia, i.e., a big, typical, demographic region in south-west Poland. All deaths occurred in agricultural circumstances, few were connected with forestry and fishing but inside agricultural farms.

The definition of fatal agricultural death and any unwitting injury resulting in death and occurring during the activity related to work on the farm or in connection with the performance of such activities or offsite as a part of normal farm activities related to agricultural activity must be consistent with the definition given by the International Labor Organization [16] and the European Agency for Safety and Health at Work (EU-OSHA) [17].

The data from forensic reports included circumstances, time and cause of death, morphological descriptions of injuries, quantitative toxicological blood tests for alcohol levels in all cases and in 21 cases tests using alternative material, i.e., urine or vitreous. The authors used the headspace gas chromatography with a flame ionization detector (HS-GC with FID, Agilent, USA) to analyze alcohol concentration in accordance with standard forensic toxicology procedures. However, due to the uncertainty of the method used and variations in alcohol concentration in the plateau phase, it was assumed that differences in the blood and alternative material $>10 \mathrm{mg} / \mathrm{dl}$ allow for the differentiation of the alcoholemia phase at the time of death: absorption or excretion phase which implicitly allows us to determine the approximate time of alcohol consumption before death. It was assumed that the absorption phase, depending on the type of alcohol consumed and the distribution of alcohol consumption over time, may last 3090 min.

The study protocol included gender, age, date, causes and circumstances of death as well as the ethyl alcohol concentration. According to the provisions of the Polish wheeled traffic and labor law it was assumed that the blood alcohol concentration (BAC) $>50 \mathrm{mg} / \mathrm{dl}$ equates to intoxication. Degrees of intoxication were evaluated with respect to the BAC as follows:

$$
\begin{aligned}
& 50-150 \mathrm{mg} / \mathrm{dl} \text { - mild intoxication, } \\
& 150-250 \mathrm{mg} / \mathrm{dl} \text { - average, } \\
& >250 \mathrm{mg} / \mathrm{dl} \text { - significant. }
\end{aligned}
$$

The authors excluded cases in which the nature of the material taken, the condition of the body and the 
results of the analysis could indicate the presence of endogenous alcohol. The study did not include deaths occurring in hospital $>24 \mathrm{~h}$ after an injury due to inadequate toxicological data related to the accident. We also excluded deaths resulting from diseases regardless of their relationships to the victims' work. Circumstances of death were divided into the following categories: traffic accidents, death caused by machinery or equipment, fire, electrocution, intoxication, death caused by animals, drowning, falling from height, crushing, burial, environmental factors (including hypothermia).

\section{RESULTS}

A total of 98 farm-related fatalities were identified between 1991-2014. At the time of the fatal accident 41 (41.8\%) out of 98 victims were intoxicated and 39 (95.1\%) out of 41 persons were males aged 19-70 years old $(<20$ years old $(\mathrm{N}=1), 20-29$ years old $(\mathrm{N}=3)$, $30-39$ years old $(\mathrm{N}=13), 40-49$ years old $(\mathrm{N}=10)$, $50-59$ years old $(\mathrm{N}=9),>60$ years old $(\mathrm{N}=3)), 2 / 41$ were females aged 37-65 years old. In the whole group liver steatosis was only reported in 2 cases and liver cirrhosis - in just 1 case. In 18/41 (43.9\%) of cases, blood tests for the concentration of ethyl alcohol revealed significant intoxication ( $>250 \mathrm{mg} / \mathrm{dl}$ ), out of which as many as $11 / 18$ cases were in the age group of $30-$ 39 years old (Table 1$)$.
The highest blood alcohol concentration was $520 \mathrm{mg} / \mathrm{dl}$ and the cause of death of a 47-year-old man was ethyl alcohol poisoning. The man died while logging in the forest. The next 2 highest results $-460 \mathrm{mg} / \mathrm{dl}$ and $370 \mathrm{mg} / \mathrm{dl}$ - were related to traffic accidents, i.e., the first person fell from a tractor's cabin and was run over by the trailer, and the second person fell from the cabin and was crushed by the tractor which had rolled over and fallen into a ditch. The victim of the first accident was a 40 -year-old male who had suffered multipleorgan damage whereas the second accident involved a 39-year-old male who had died of suffocation as a result of rapid chest immobilization. In both cases the nature of the injuries indicated that they had occurred during life pointing to traumatic death rather than lethal intoxication. In total, ethyl alcohol intoxication was found to be the sole cause of death in 3 cases.

There were only 2 women in the group of intoxicated victims. The first, a 37-year-old, died of hypothermia and her BAC was $70 \mathrm{mg} / \mathrm{dl}$. The second, a 65 -year-old, drowned in a water tank located on the farm and her BAC was $220 \mathrm{mg} / \mathrm{dl}$. Out of the 41 positive BAC cases, in 21 cases alcohol concentration was determined using alternative material (urine or vitreous) to obtain a significant $(>10 \mathrm{mg} / \mathrm{dl}$ ) difference in 20 cases as compared to the blood tests. In 1 case, comparable concentrations of alcohol in blood and urine indicated a phase of leveled concentrations. In 16/21 (76\%) cases, at the time of death victims were in the alcohol eli-

Table 1. Age and blood alcohol concentration of the victims in fatal farm-related incidents in Lower Silesia in Poland, 1991-2014 Tabela 1. Wiek i stężenie alkoholu we krwi ofiar śmiertelnych wypadków przy pracy w rolnictwie na Dolnym Śląsku w Polsce w latach 1991-2014

\begin{tabular}{|c|c|c|c|c|c|}
\hline \multirow{2}{*}{$\begin{array}{l}\text { Age } \\
\text { [years] } \\
\text { Wiek } \\
\text { [w latach] }\end{array}$} & \multicolumn{5}{|c|}{$\begin{array}{l}\text { Fatalities with blood alcohol concentration } \\
\text { Ofiary śmiertelne z różnym stężeniem alkoholu we krwi } \\
\text { [n] }\end{array}$} \\
\hline & $\begin{array}{c}50-150 \mathrm{mg} / \mathrm{dl} \\
0,5-1,5 \% \text { o }\end{array}$ & $\begin{array}{c}150-250 \mathrm{mg} / \mathrm{dl} \\
1,5-2,5 \%\end{array}$ & $\begin{array}{c}>250 \mathrm{mg} / \mathrm{dl} \\
>2,5 \%\end{array}$ & $\begin{array}{c}\text { total } \\
\text { ogółem }\end{array}$ & $\begin{array}{l}\text { total } \\
\text { ogółem }\end{array}$ \\
\hline $20-29$ & $1^{*}$ & $2^{*}$ & 0 & 3 & 6 \\
\hline $30-39$ & $1^{\star *}$ & $2^{*}$ & $11^{*}$ & 14 & 24 \\
\hline $40-49$ & $2^{*}$ & $4^{*}$ & $4^{*}$ & 10 & 23 \\
\hline $50-59$ & $4^{*}$ & $4^{*}$ & $1^{*}$ & 9 & 24 \\
\hline
\end{tabular}

* Males / Mężczyźni.

${ }^{*}$ Females / Kobiety. 
mination phase, and in 4/21 (19\%) cases they were in the alcohol absorption phase. Out of 20 traffic accidents and accidents involving machinery, the results allow the alcoholemia phase to be determined in 12 cases, out of which 11 victims were in the elimination phase.

The most common (16/41) cause of death in victims with proven alcohol intoxication was a traffic accident, i.e., being run over or hit by a moving vehicle (a tractor, a trailer, a combine-harvester, a water cart, a drill, a horse-drawn carriage). The next most common cause of death (in 5 cases) was drowning. The third (in 4 cases) most common cause of farm-related death was being caught or hit by moving parts of machinery or equipment (Table 2).

The most common injury found during the autopsies (regardless of the cause of death and alcohol intoxication) was multiple organ damage (48/98). Twentytwo out of 48 victims in this group were intoxicated, with 10 being significantly intoxicated. In the group of intoxicated victims (41/98) the second most frequent type of injury was chest injury (9/41), which occurred following traffic accidents, accidents with machinery, burials and crushing. During these accidents, the most common cause of death was blunt chest trauma with immobilization and inability to breathe. At the same time, chest injuries occurred in 17/98 cases of agriculture accidents during this period (regardless of alcohol intoxication). In 8/98 cases the autopsy revealed lethal isolated craniocerebral injuries with 2 people intoxicated. Forty-one out of the 98 accidents (41.8\%) occurred during the intensive fieldwork season (between May and November). Almost half (19/41) of the cases of intoxication occurred during this period.

\section{DISCUSSION}

The authors draw our attention to the high percentage rate of intoxicated agricultural workers (> 41\%) who had fatal occupational accidents and the large number of farmers significantly intoxicated (with the BAC $>250 \mathrm{mg} / \mathrm{dl}$ in $43.9 \%$ of all the cases examined). Although observations made by other investigators also

Table 2. Circumstances of fatal farm-related incidents and blood alcohol concentration of the victims in Lower Silesia in Poland, 1991-2014

Tabela 2. Okoliczności śmiertelnych wypadków przy pracy w rolnictwie a stężenie alkoholu we krwi ofiar na Dolnym Śląsku w Polsce w latach 1991-2014

\begin{tabular}{|c|c|c|c|c|c|}
\hline \multirow{3}{*}{$\begin{array}{l}\text { Death circumstances } \\
\text { Okoliczności śmierci }\end{array}$} & \multicolumn{5}{|c|}{$\begin{array}{l}\text { Fatalities with blood alcohol concentration } \\
\text { Ofiary śmiertelne z różnym stężeniem alkoholu we krwi } \\
\qquad[\mathrm{n}]\end{array}$} \\
\hline & \multicolumn{4}{|c|}{$\begin{array}{c}\text { intoxicated } \\
\text { w stanie nietrzeźwości }\end{array}$} & \multirow{2}{*}{$\begin{array}{l}\text { total } \\
\text { ogółem }\end{array}$} \\
\hline & $\begin{array}{c}50-150 \mathrm{mg} / \mathrm{dl} \\
0,5-1,5 \%\end{array}$ & $\begin{array}{c}150-250 \mathrm{mg} / \mathrm{dl} \\
1,5-2,5 \% \mathrm{o}\end{array}$ & $\begin{array}{c}>250 \mathrm{mg} / \mathrm{dl} \\
>2,5 \%\end{array}$ & $\begin{array}{c}\text { total } \\
\text { ogółem }\end{array}$ & \\
\hline $\begin{array}{l}\text { Being caught in or hit by moving parts of agricultural } \\
\text { machinery or equipment / Pochwycenie/uderzenie } \\
\text { przez poruszające się elementy maszyn rolniczych }\end{array}$ & 3 & 1 & 0 & 4 & 15 \\
\hline Fire / Pożar & 0 & 1 & 1 & 2 & 4 \\
\hline Electrocution / Porażenie prądem & 0 & 0 & 0 & 0 & 2 \\
\hline Crushing / Przygniecenie & 3 & 1 & 1 & 5 & 17 \\
\hline Environmental factors / Czynniki środkowiskowe & 1 & 1 & 0 & 2 & 5 \\
\hline $\begin{array}{l}\text { Alcohol intoxication (as the only known } \\
\text { circumstance) / Zatrucie alkoholem (jako jedyna } \\
\text { znana okoliczność) }\end{array}$ & 0 & 0 & 3 & 3 & 3 \\
\hline $\begin{array}{l}\text { Other intoxication (as the only known circumstance) / } \\
\text { Inne zatrucie (jako jedyna znana okoliczność) }\end{array}$ & 0 & 0 & 0 & 0 & 3 \\
\hline Total / Ogółem & 8 & 15 & 18 & 41 & 98 \\
\hline
\end{tabular}


indicate alcohol as a risk factor in accidents, the percentage rate of intoxicated workers was not as high. In addition, these indicators are clearly lower in developed countries. In an Australian study, authors reported blood alcohol readings $>50 \mathrm{mg} / \mathrm{dl}$ in only $20.7 \%$ of victims of fatal agricultural accidents in the age group of $15-24$ years old, and in $11.9 \%$ of victims in the age group $\geq 55$ years old [18]. McNeilly reported that in the State of Victoria (Australia), the positive BAC was only reported in $7 \%$ of all agricultural accidents in the years 2001-2006 [19]. A similar American study (Texas, Harris County) of agricultural accident victims reported intoxication in 13.3\% [5].

In addition, in the studies which analyzed all workrelated accidents, regardless of the industry, the number of intoxicated victims was much lower than in our study. In Jordan this rate was $9.1 \%$ among 88 victims of all work-related accidents subjected to autopsies between 2008-2012 [11]. Similar values, i.e., 11\%, were reported following the examination of victims of occupational accidents in another American report from North Carolina [20].

The aforementioned studies were conducted in countries which are demographically, culturally and economically different from Poland, which may have also influenced the results obtained. A lower percentage rate of people intoxicated, although not as low as in the works cited, was also reported in the Serbian study where deaths occurring between 1996-2008 were examined (Serbia's economic and demographic structure is similar to that in Poland). Out of 337 cases of work-related fatal accidents (not just in agriculture), the victims of which were subjected to blood alcohol content test, the BAC $>50 \mathrm{mg} / \mathrm{dl}$ was found in $24 \%$ of cases, mostly in men, and in the majority of results it did not exceed $150 \mathrm{mg} / \mathrm{dl}$ [8]. Some authors of those reports clearly indicate that blood alcohol content tests were not carried out in all the analyzed cases.

One of the factors which should be considered when interpreting the results obtained is varied alcohol consumption per capita depending on the size of the country. This indicator is higher in Poland than the European and North American average but not high enough to fully explain the scale of such divergences [21]. As there is no scientific publications from Poland, our results can't be compared to other data on intoxication in fatal work-related accidents in Poland. What is consistent in all similar studies is that substantially more men than women drink alcohol at work $[2,4,22,23]$, which is also consistent with the data on worldwide alcohol consumption according to gender [21]. In our study, this ratio equaled 39:2 and resulted mainly from the nature of the agricultural work where difficult, physical and risky tasks are performed by men.

The relationship between the BAC values and the circumstances of accidents at work and injuries suffered was examined by Foster and Dissanaike [10]. In 2007-2011, 504 Trauma Center patients who sustained work-related injuries were tested for the BAC upon admission $-4.5 \%$ of them were blood alcohol concentration positive (according to the legal BAC limits in Texas which equaled $80 \mathrm{mg} / \mathrm{dl}$ ). A significant positive correlation between the degree of intoxication and the severity of injuries was reported especially on farms, which accounted for as many as $48.6 \%$ of all serious injuries where the positive BAC was observed. This is consistent with the results of our study in which a large number of the highest BAC values $(>250 \mathrm{mg} / \mathrm{dl})$ was observed in traffic accidents $(62.5 \%$ of all the positive BAC cases related to traffic accidents) and polytrauma (48/98 agricultural fatalities with multiple organ damage, out of which 22 had the positive BAC and 10 had the BAC $>250 \mathrm{mg} / \mathrm{dl}$ ). This proves that there is a greater likelihood of severe, fatal injuries when the BAC is high and a higher accident rate when operating vehicles.

The issue of traffic accidents involving intoxicated agricultural workers is significant when it comes to the type of vehicles used $[2,4,22,23]$ drew attention to the particularly dangerous accidents involving tractors, i.e., tractors rolling over, the victim being run over, crushed or pinned down by the tractor [22] Similar information is provided by the Centers for Disease Control and Prevention (CDC) databases [23]. Our observations are in line with the latter as, out of 32 traffic accidents, 20 involved tractors, 9/20 were crushings by an overturned tractor and 11/20 involved falling out of the cabin. Tractors are dangerous vehicles because their centre of gravity is high and their track width is relatively narrow, which makes them prone to tipping over. Some older tractors have unprotected cabins and cabin doors are left open during work, there are too many people inside, especially on the way to or from work, and all this results in people falling out of the cabin [24-26].

In our study group, almost a half of traffic accident victims were intoxicated (16/32), including $4 / 11$ of those who fell from the tractor. The main way of reducing the number of accidents is the removal of the so-called 
"dangerous tractors" from widespread use [24,26,27]. Modern tractors have in-vehicle breathalyzers (breath alcohol ignition interlock device - BAIID) which prevent operation by intoxicated workers. They also have air-conditioned cabins with seatbelts and widewheel track systems and vehicles equipped with a rollover protective structure (ROPS) are much safer [25,27] both for intoxicated and sober operators. However, the high cost may hinder their sale. According to our results, a large group of fatal accidents involved incidents with dynamic machinery other than vehicles (15/98 of all accidents out of which 4/15 victims had the positive BAC). The circumstances of the deaths were mainly related to being caught or hit by moving parts of machines or being crushed, which could be connected to the fact that alcohol hinders psychophysical abilities.

One objective of this work, in addition to establishing the prevalence of intoxication among victims of fatal accidents in agriculture, was to analyze the time between alcohol consumption and carrying out risky jobs and, finally, between alcohol consumption and fatal accidents. The link between alcohol consumption and the risk of accidents has already been discussed by some researchers. None of them, however, has objectively estimated the time of alcohol consumption.

Wang et al. reported that a lower incidence of accidents occurred in patients who consumed alcohol before taking up work, which is not consistent with a similar Indian study $[7,28]$. Toxicological data obtained from the examination of 2 types of biological material for the presence of ethyl alcohol, i.e., either blood or urine or vitreous, additionally allowed us to analyze the time and the manner of alcohol consumption before death. Such information may be of paramount importance for creating systems prohibiting or excluding intoxicated workers from carrying out and performing work. Bearing in mind that work on a farm is often time-consuming, lasts all-day, often without supervision, and breaks may be taken at any time, it should be assumed that alcohol is not just consumed before work but also during breaks or at work. This situation significantly impedes the initiation of preventive actions and involves implementing a more complex control system.

The authors reported that an overwhelming number of victims (16 of 21) for whom the alcoholemia phase could be determined was in the elimination phase. Assuming that the alcohol consumption was extended over some period of time, this meant that consumption had taken place at least $1 \mathrm{~h}$ before death. What is more, in the majority of cases in the elimination phase, the BAC was $>250 \mathrm{mg} / \mathrm{dl}$ and almost all the cases involved a traffic or machinery accident. The positive here is that if there is a period of time between alcohol consumption and the accident, appropriately designed and implemented supervisory systems designed to control the sobriety of workers could be used for signaling and averting dangers, in order to avoid tragedy. In the cases analyzed, the future victims were intoxicated even $1 \mathrm{~h}$ after alcohol consumption. Despite the fact that intoxication symptoms were obvious to them and to their colleagues, they began or continued with professional activities. This proves that intoxicated workers and their environment lacked critical assessment regarding the influence of alcohol on mental and physical condition; they were unaware of or even ignored the threats posed by alcohol.

The consideration of the alcohol consumption of agricultural workers in the context of the frequency of accidents comes down to 2 concepts: consumers' tolerance to alcohol [29] and the influence of alcohol on the frequency and fatal outcome of work-related accidents which, among other things, is evident in our results. In their questionnaire study of the agricultural population in the northern provinces of China, Wang et al. [7] found a positive correlation between the frequency of alcohol consumption, the amount consumed and past alcoholism with an increased number of accidents. Similarly, in a study conducted in Finland [29], where alcohol consumption per capita is similar to that found in Poland [21] it was reported that mortality rates were highest among people with the highest number of heavy drinking episodes. However, our study does not allow us to draw similar conclusions. It is surprising that in the 41 cases examined, alterations were only observed in 2 , and they were presumably related to alcoholism, liver cirrhosis or liver steatosis.

This study also has several limitations. First of all, the material only concerns 1 demographic region and has been retrospectively collected by only 1 institution. The relatively limited number of cases and their diversity make it impossible to conduct a more detailed analysis than the one presented here as well as to draw more general conclusions. Moreover, alcohol concentrations in blood and in the alternative material were not determined at the same time in all cases, which could also have influenced the presented data. 


\section{CONCLUSIONS}

Alcohol consumption is a crucial risk factor in fatal agricultural accidents, especially in those related to traffic accidents and the operation of machinery or equipment. Due to the fact that forensic autopsy reports are extremely detailed, they provide more accurate information than other medical records or analyses prepared by the occupational safety services. So as to determine the time of alcohol consumption, all victims of agricultural accidents should be tested for alcohol concentration in their blood and urine or vitreous. To increase safety at work, considering that the alcohol was consumed at various times at work (before and during work) breath alcohol concentration should be checked both before and during work. It should also be emphasized that intoxicated workers must not operate vehicles and agricultural machinery it is therefore appropriate to promote BAIID solutions or even implement them as a legal requirement. Finally, there is a need to educate agricultural workers on the dangers posed by alcohol consumption.

\section{REFERENCES}

1. International Labour Organization. ILO introductory report: Global trends and challenges on occupational safety and health: XIX World Congress on Safety and Health at Work: Istanbul, Turkey, 11-15 September 2011 [Internet]. Geneva: The Organization; 2011 [cited 2015 Jun 1]. Available from: http://www.ilo.org/wcmsp5/ groups/public/@ed_protect/@protrav/@safework/documents/publication/wcms_162662.pdf.

2. [Central Statistical Office. Statistical yearbook of Poland 2013] [Internet]. Warszawa: The Office; 2013 [cited 2015 Mar 20]. Available from: http://stat.gov.pl/ obszary-tematyczne/roczniki-statystyczne/roczniki-statystyczne/rocznik-statystyczny-rzeczypospolitej-polskiej2013,2,8.html. Polish.

3. Rorat M, Thannhauser A, Jurek T. Analysis of injuries and causes of death in fatal farm-related incidents in Lower Silesia, Poland. Ann Agric Environ Med. 2015;22(2):271-4, https://doi.org/10.5604/12321966.11 52079 .

4. [Agricultural Social Insurance Fund] [Internet]. Warszawa: The Fund; 2015 [cited 2015 Oct 22]. [Current statistics on work-related incidents in agriculture]. Available from: http://www.krus.gov.pl/aktualnosci/dokument/artykul/aktualne-statystyki-o-wypadkach-przypracy-w-gospodarstwach-rolnych. Polish.
5. Lewis RJ, Cooper SP. Alcohol, other drugs, and fatal work-related injuries. J Occup Med. 1989;31(1):23-8.

6. Zhou C, Roseman JM. Agricultural injuries among a population-based sample of farm operators in Alabama. Am J Ind Med. 1994;25(3):385-402, https://doi.org/10. 1002/ajim.4700250307.

7. Wang L, Wheeler K, Bai L, Stallones L, Dong Y, Ge J, et al. Alcohol consumption and work-related injuries among farmers in Heilongjiang Province, People's Republic of China. Am J Ind Med. 2010;53(8):825-35, https://doi. org/10.1002/ajim.20817.

8. Todorovic MS, Todorovic DV, Matejic S, Minic ZS, Stnakovic V, Preljevic I, et al. The role of alcohol in fatal work related injuries. Health Med. 2012;6:648-53.

9. Ramirez M, Bedford R, Sullivan R, Anthony TR, Kraemer J, Faine B, et al. Toxicology testing in fatally injured workers: A review of five years of Iowa FACE cases. Int J Environ Res Public Health. 2013;10(11):6154-68, https://doi.org/10.3390/ijerph10116154.

10. Foster CA, Dissanaike SD. Prevalence and consequences of positive blood alcohol levels among patients injured at work. J Emerg Trauma Shock. 2014;7(4):268-73, https:// doi.org/10.4103/0974-2700.142748.

11. Al-Abdallat EM, Oqailan AMA, Ali RA, Hudaib AA, Salameh GAM. Occupational fatalities in Jordan. J Forensic Leg Med. 2014;29:25-9, https://doi.org/10.1016/ j.jflm.2014.11.001.

12. Lyman S, McGwin G Jr, Enochs R, Roseman JM. History of agricultural injury among farmers in Alabama and Mississippi: Prevalence, characteristics, and associated factors. Am J Ind Med. 1999;35(5):499-510.

13. Stallones L, Xiang H. Alcohol consumption patterns and work-related injuries among Colorado farm residents. Am J Prev Med. 2003;25(1):25-30.

14. Grzywacz JG, Quandt SA, Isom S, Arcury TA. Alcohol use among immigrant Latino farm workers in North Carolina. Am J Ind Med. 2007;50(8):617-25.

15. Berry JG, Pidd K, Roche AM, Harrison JE. Prevalence and patterns of alcohol use in the Australian workforce: Findings from the 2001 National Drug Strategy Household Survey. Addiction. 2007;102(9):1399-410.

16. International Labour Organization [Internet]. Geneva: The Organization; 2012 [cited 2015 Apr 1]. Improvement of national reporting, data collection and analysis of occupational accidents and diseases. Available from: http:// www.ilo.org/safework/info/publications/WCMS_2074 14/lang--en/index.htm.

17. European Agency for Safety and Health at Work [Internet]. Bilbao: The Agency; 2011 [cited 2015 Aug 21]. Maintenance in agriculture - A safety and health guide. 
Available from: https://osha.europa.eu/en/tools-and-publications/publications/reports/maintenance-in-agri-culture-a-safety-and-health-guide/view.

18. Mitchell RJ, Franklin RC, Driscoll TR, Fragar LJ. Farmrelated fatal injury of young and older adults in Australia, 1989-1992. Aust J Rural Health. 2002;10(4): 209-19.

19. McNeilly B, Ibrahim JE, Bugeja L, Ozanne-Smith J. The prevalence of work-related deaths associated with alcohol and drugs in Victoria, Australia, 2001-2006. Inj Prev. 2010;16(6):423-8, https://doi.org/10.1136/ip.2010.027052.

20. Sniezek JE, Horiagon TM. Medical-examiner-reported fatal occupational injuries, North Carolina, 1978-1984. Am J Ind Med. 1989;15(6):669-78.

21. World Health Organization. Global status report on alcohol and health 2014 [Internet]. Geneva: The Organization; 2014 [cited 2015 Oct 22]. Available from: http://apps.who.int/iris/bitstream/10665/112736/1/9789 240692763_eng.pdf.

22. Carndall CS, Fullerton L, Olson L, Sklar DP, Zumwalt R. Farm-related injury mortality in New Mexico, 19801991. Accid Anal Prev. 1997;29(2):257-61.

23. Centers for Disease Control and Prevention [Internet]. Atlanta: The Centers; 2014 [cited 2015 Aug 30]. Agri- cultural safety. Available from: http://www.cdc.gov/niosh/ topics/aginjury.

24. Myers JR, Hendricks KJ. Agricultural tractor overturn deaths: Assessment of trends and risk factors. Am J Ind Med. 2010;53(7):662-72, https://doi.org/10.1002/ajim. 20775.

25. Myers ML, Cole HP, Westneat SC. Seatbelt use during tractor overturns. J Agric Saf Health. 2006;12(1):43-9.

26. Murphy DJ, Myers J, McKenzie EA Jr, Cavaletto R, May J, Sorensen J. Tractors and rollover protection in the United States. J Agromedicine. 2010;15(3):249-63, https://doi. org/10.1080/1059924X.2010.484309.

27. DeGroot JM, Isaacs C, Pickett W, Brison RJ. Patterns of fatal machine rollovers in Canadian agriculture. Chronic Dis Inj Can. 2011;31(3):97-102.

28. Kunar BM, Bhattacherjee A, Chau N. Relationships of job hazards, lack of knowledge, alcohol use, health status and risk taking behavior to work injury of coal miners: A case-control study in India. J Occup Health. 2008; 50(3):236-44.

29. Paljärvi T, Mäkelä P, Poikolainen K. Pattern of drinking and fatal injury: A population-based follow-up study of Finnish men. Addiction. 2005;100(3):1851-9.

This work is available in Open Access model and licensed under a Creative Commons Attribution-NonCommercial 3.0 Poland License / Ten utwór jest dostępny w modelu open access na licencji Creative Commons Uznanie autorstwa - Użycie niekomercyjne 3.0 Polska - http://creativecommons.org/ licenses/by-nc/3.0/pl/deed.en. 